\title{
PROBLEMATIK PEMBELAJARAN DARING MATA KULIAH BAHASA INDONESIA
}

\author{
Yeni Ernawati \\ Dosen Universitas Bina Darma \\ Jalan Jenderal Ahmad Yani No.3 Palembang \\ Sur-el: yeni.ernawati@binadarma.ac.id
}

Article info

Article history:

Received:13-02-2020

Revised :24-03-2020

Accepted:05-05-2020

Keywords:

Learnings Problems,

Online, Indonesia

Language, E-learning

Kata Kunci:

Problematika

Pembelajaran,

Daring, Bahasa

Indonesia, E-learning

\begin{abstract}
A B S T R A C T
This study aims to describe the problematics of online learning in Indonesian language courses. This research is descriptive research. The aim of this research is problematic learning in Indonesian language courses online. The data in this study are learning problems that occur in Indonesian language learning activities. Researchers make observations and documentation to collect data. Based on observations and data collection, it is known that online learning in Indonesian courses, there are several learning problems. The problematic of online learning that occurs in the learning process of Indonesian courses occurs in the learning components. Learning problems occur in (1) learning facilities or media and infrastructure, namely e-learning and internet access; (2) presentation of material and use of learning methods; (3) discussion activities, and (4) learning assessment. During the learning process by establishing good communication with students, as well as efforts to hold effective learning, the teacher determines learning techniques that can minimize these problems.
\end{abstract}

Penelitian ini bertujuan untuk mendeskripsikan problematik pembelajaran daring pada mata kkuliah Bahasa Indonesia. Penelitian ini merupakan penelitian deskriptif. Sasaran penelitan ini adalah problematik pembelajaran pada mata kuliah bahasa Indonesia secara daring. Data dalam penelitian ini adalah problematik pembelajaran yang terjadi dalam kegiatan pembelajaran mata kuliah Bahasa Indonesia. Peneliti melakukan pengamatan dan dokumentasi untuk mengumpulkan data. Berdasakan hasil pengamatan dan pengumpulan data diketahui bahwa dalam pembelajaran daring mata kuliah Bahasa Indonesia, terdapat beberapa problematik pembelajaran. Adapun problematik pembelajaran daring yang terjadi dalam proses pembelajaran mata kuliah Bahasa Indonesia terjadi pada komponen-komponen pembelajaran. Problematik pembelajaran terjadi pada (1) sarana atau media dan prasarana pembelajaran, yaitu elearning dan akses internet; (2) penyajian materi dan penggunaan metode pemebelajaran; (3) kegiatan diskusi, dan (4) penilaian pembelajaran. Selama proses pembelajaran dengan menjalin komunikasi yang baik dengan mahasiswa, serta upaya untuk mengadakan pembelajaran yang efektif, pengajar menentukan teknik-teknik pembelajaran yang dapat meminimalisasi problematik tersebut.

Direktorat Riset dan Pengabdian Masyarakat Universitas Bina Darma. 


\section{JURNAL ILMIAH \\ BINA EDUKASI \\ ISSN 1979-8598 E-ISSN: 2655-8378 \\ http://journal.binadarma.ac.id/index.php/jurnalbinaedukasi \\ Vol. 13, No. 1, Juni 2020, 01 -- 15}

\section{PENDAHULUAN}

Pandemi Covid-19 melanda sejak awal 2020 di Indonesia. Banyak masyarakat yang terjangkit virus ini. Oleh karena itu, pemerintah melakukan segala upaya untuk memutus penyebaran virus korona ini. Upaya-upaya tersebut diantaranya adalah melakukan karantina wilayah, pembatasan sosial berskala besar, serta penerapan protokol kesehatan yang ketat. Seluruh kegiatan yang melibatkan banyak orang dibatasi bahkan dilarang. Salah satunya adalah kegiatan belajar, dari tingkat Pendidikan Anak Usia Dini (PAUD) sampai dengan Perguruan Tinggi.

Sejak Maret 2020, Universitas Bina Darma turut mendukung upaya pemerintah untuk memutus penyebaran Pandemi Covid-19 dengan melakukan karantina bagi mahasiswa, pengajar, dan karyawan. Oleh sebab itu, seluruh kegiatan akademik yang biasa dilakukan secara langsung ditiadakan. Seluruh kegiatan akademik dilakukan secara daring (online). Salah satunya adalah kegiatan pembelajaran. Pembelajaran daring ini menggunakan e-learning sebagai sarana utamanya.

Kegiatan pembelajaran daring sudah diterapkan sejak lama tetapi menggunakan sistem blended learning dengan rasio tujuh pertemuan tatap muka dan enam pembelajaran daring. Sejak masa karantina, seluruh kegiatan belajar-mengajar dilakukan melalui e-learning secara penuh dari pertemuan pertama sampai dengan pertemuan terakhir. Salah satunya adalah Mata Kuliah (MK) Bahasa Indonesia. Dengan pembelajaran daring ini, mahasiswa dapat tetap melakukan perkuliahan meski sedang karantina di rumah.

Pembelajaran daring MK Bahasa Indonesia dilakukan dengan rentang waktu 7 hari untuk setiap sesi pembelajaran. Pembelajaran daring MK Bahasa Indonesia melalui e-learning ini terdiri dari lima aspek kegiatan. Adapun aspek kegiatan pembelajaran daring MK Bahasa Indonesia setiap minggu adalah (a) pengunggahan materi; (b) pencantuman tautan referensi; (c) forum diskusi, (d) latihan atau tugas, dan (e) penilaian.

Perubahan sistem pembelajaran dari pembelajaran secara tatap muka ke pembelajaran daring ini tentu menimbulkan beberapa masalah dalam kegiatan pembelajaran. Terutama bagi pengajar dan pembelajar, yaitu dosen dan mahasiswa. Meskipun sebelumnya, kegiatan pembelajaran daring ini sudah sering dilakukan dalam beberapa sesi pertemuan. Dengan sistem blended learning, mahasiswa masih berkesempatan mengikuti kelas tatap muka sedangkan dalam pembelajaran daring selama masa pandemik Covid-19 ini, mahasiswa benar-benar belajar secara mandiri.

Problematik pembelajaran daring ini terjadi pada komponen-komponen pembelajaran. Beberapa diantaranya adalah kesiapan sarana pembelajaran daring yang digunakan. Pada mingguminggu pertama, mahasiwa mengeluhkan kesulitan mengakses e-learning. Jika sebelumnya 


\section{JURNAL ILMIAH \\ BINA EDUKASI \\ ISSN 1979-8598 E-ISSN: 2655-8378 \\ http://journal.binadarma.ac.id/index.php/jurnalbinaedukasi \\ Vol. 13, No. 1, Juni 2020, 01 -- 15}

pengaksesan e-learning untuk pembelajaran tidak ramai maka selama penerapan pembelajaran daring ini, menjadi begitu padat. Semua dosen dan mahasiswa mengakses e-learning. Ketersediaan dan kemudahan akses jaringan internet di beberapa wilayah pelosok juga menjadi masalah yang menyebabkan ketidaklancaran kegiatan pembelajaran daring.

Selain itu, penyajian materi juga harus disesuaikan dengan sistem pembelajaran daring yang bersifat tidak langsung. Pengajar tidak dapat menggunakan video konferensi untuk setiap sesi pembelajaran. Sebab, mahasiswa yang 'pulang kampung' dan berada di wilayah yang sulit akses internetnya tentu tidak dapat mengikuti kegiatan pembelajaran tatap maya. Jadi pembelajaran tidak akan kondusif karena tidak semua mahasiswa berpartisipasi.

Kegiatan diskusi juga tidak seperti diskusi pada kelas tatap muka. Kegiatan pembelajaran daring ini bersifat tidak langsung, maka kegiatan diskusi juga tidak dapat dilakukan dengan cepat serta tidak semua mahasiswa mau bergabung dalam kegiatan diskusi. Hal ini menjadi masalah yang perlu diperhatikan dan dicari solusinya oleh pengajar. Latihan atau tugas juga menjadi salah satu masalah utama dalam pembelajaran daring. Semua pengajar memberikan latihan atau tugas pada mahasiswa. Misal mahasiwa kelas UBD1D mengambil delapan MK pada semester yang sama, maka mereka harus mengerjakan delapan latihan atau tugas dalam satu minggu. Hal tersebut sangat memberatkan mahasiswa. Oleh karena itu mahasiswa dan pengajar harus selalu berkomunikasi sehingga dapat menemukan pemecahan masalah yang tepat bagi semua pihak.

Berdasarkan uraian alasan tersebut, maka peneliti berupaya mendeskripsikan problematik pembelajaran daring yang terjadi pada MK Bahasa Indonesia dan menerapkan beberapa teknik pembelajaran yang dapat meminimalisasi problematik tersebut. Penelitian tentang pembelajaran daring juga telah dilakukan oleh beberapa peneliti. Pertama, Mustofa dkk. (2019) dengan judul "Formulasi Model Perkuliahan Daring Sebagai Upaya Menekan Disparitas Kualitas Perguruan Tinggi" dengan hasil penelitian yang menunjukkan bahwa uruan tinggi di Indonesia. Indikasi seperti 1) Meminimalkan keterbatasan akses ke pendidikan tinggi yang memiliki kualitas tertentu. 2) Memotong keterbatasan fasilitas yang telah dipertimbangkan sebagai salah satu kendala dari rendahnya kualitas pendidikan tinggi. 3) Menghilangkan batasan pengertian pada materi tertentu. 4) Sistem kuliah online memberikan akses luas ke sumber daya pendidikan, terutama di universitas terkemuka. Kedua, Riyanda, Herlina, dan Wicaksono (2020) dengan judul "Evaluasi Implementasi Sistem Pembelajaran Daring Fakultas Keguruan dan Ilmu Pendidikan Universitas Lampung" dengan hasil penelitian yang menunjukkan bahwa tingkat pencapaian program sistem pembelajaran daring pada komponen context memperoleh skor rata-rata 4,145 $(82,91 \%)$ digolongkan dalam kategori baik; komponen input memperoleh skor ratarata 4,302 $(86,04 \%)$ digolongkan dalam kategori baik; komponen process memperoleh skor rata-rata 3,838 (76,76\%) digolongkan dalam kategori cukup; dan komponen product yang memperoleh skor rata-rata 4,107 $(82,13 \%)$ digolongkan dalam kategori baik. Dari hasil penelitian dapat disimpulkan bahwa 


\section{JURNAL ILMIAH}

BINA EDUKASI

ISSN 1979-8598 E-ISSN: 2655-8378

http://journal.binadarma.ac.id/index.php/jurnalbinaedukasi

Vol. 13, No. 1, Juni 2020, 01 -- 15

program sistem pembelajaran daring dilingkungan PMIPA FKIP Unila secara keseluruhan sudah lumayan baik sehingga bisa tetap dilanjutkan.

Ketiga, Sofyana dan Rozaq (2019) dengan judul "Pembelajaran Daring Kombinasi Berbasis Whatsapp pada Kelas Karyawan Prodi Teknik Informatika Universitas PGRI Madiun" dengan hasil penelitian yang menunjukkan bahwa $69 \%$ responden menyatakan pembelajaran secara konvensional kurang efektif, $89 \%$ responden berminat dalam pembelajaran daring, dan $78 \%$ responden setuju bahwa penerapan pembelajaran daring kombinasi berbasis whatsapp lebih efektif daripada pembelajaran konvensional.

\section{METODOLOGI PENELITIAN}

\subsection{Problematik Pembelajaran}

Dalam KBBI, problematik didefinisikan sebagai hal yang masih belum bisa dipecahkan; permasalahan. Pembelajaran adalah kegiatan yang dilakukan untuk menginisiasi, memfasilitasi, dan meningkatkan intensitas dan kualitas belajar pada diri peserta didik (Winataputra dkk., 2016). Dimyati (Hayati, 2017) mengemukakan bahwa hakikat pembelajaran adalah proses interaksi antara pengajar dan pembelajar yang melibatkan komponen-komponen belajar, seperti tujuan belajar, materi/sumber belajar, sistem penyajian dan penilaian pada suatu lingkungan belajar. Berdasarkan definisi tersebut, dapat dirumuskan pengertian dari problematik pembelajaran. Problematik pembelajaran adalah permasalahan yang terjadi pada kegiatan pembelajaran, baik pada proses penginisasian, penfasilitasan, maupun peningkatan intensitas dan kualitas belajar yang berkaitan dengan tujuan pembelajaran, pengajar, pembelajar, materi, metode, dan penilaian dalam suatu lingkungan belajar. Jadi, problematik pembelajaran dapat terjadi pada komponenkomponen pembelajaran. Riyana (2011) mengemukakan bahwa dalam pembelajaran terdapat komponen-komponen, yaitu tujuan pembelajaran, materi/bahan pembelajaran, media dan metode pembelajaran, serta peserta didik dan pendidik.

\subsection{Pembelajaran Daring}

Bilfaqih dan Qomarudin (2015) mendefinisilan pembelajaran daring sebagai program penyelenggaraan kelas pembelajaran dalam jaringan untuk menjangkau kelompok target yang masif dan luas. Senada dengan definisi tersebut, Adhe dikutip oleh Sofyana dan Rozaq (2019) juga mengemukakan bahwa pembelajaran daring bertujuan memberikan layanan pembelajaran bermutu dalam jaringan (daring) yang bersifat masif dan terbuka untuk menjangkau peminat yang lebih banyak dan lebih luas. Jadi, pembelajaran daring adalah program pembelajaran secara daring (online) yang bertujuan untuk menjangkau kelompok belajar yang luas yang bersifat masif dan terbuka. 


\section{JURNAL ILMIAH \\ BINA EDUKASI \\ ISSN 1979-8598 E-ISSN: 2655-8378 \\ http://journal.binadarma.ac.id/index.php/jurnalbinaedukasi \\ Vol. 13, No. 1, Juni 2020, 01 -- 15}

Berdasarkan definisi tersebut, dapat kita ketahui bahwa ada tiga karakteristik dari pembelajaran daring. Bilfaqih dan Qomarudin (2015) menjelaskan ketiga karakterisktik pembelajaran daring tersebut adalah 'daring', 'masif', dan 'terbuka'.

1) Daring

Pembelajaran dilakukan dengan memanfaatkan jaringan internet (dalam jaringan /online).

Setiap pelajaran dilengkapi dengan materi, berupa rekaman audio atau slideshow serta tugas mingguan. Tugas-tugas tersebut dikerjakan dengan batas waktu pengerjaan yang telah ditentukan dengan sistem penilaian yang bervariasi.

2) Masif

Partisipan pembelajaran daring tidak dibatasi atau tanpa batas. Contohnya: Ruang Guru merupakan salah satu program pembelajaran daring dengan 15 juta pengguna.

3) Terbuka

Pembelajaran daring dapat diikuti oleh siapapun tanpa memandang usia, latar belakang, dan tanpa syarat apapun. Siapapun yang ingin belajar dapat mengakses situs-situs pembelajaran daring.

Untuk karakteristik kedua dan ketiga ini tergantung pada desain, pengembang, dan penyelenggara program pembelajaran. Ada program pembelajaran yang membatasi jumlah partispan dan membebankan biaya untuk program pembelajaran tertentu.

Program pembelajaran daring memberikan banyak manfaat dalam dunia pendidikan. Bilfaqih dan Qomarudin (2015) mengemukakan manfaat pembelajaran daring adalah sebagai berikut.

a. Meningkatkan mutu pendidikan/pelatihan dengan memanfaatkan multimedia secara efektif dalam pembelajaran.

b. Meningkatkan keterjangkauan pendidikan/pelatihan yang bermutu melalui penyelenggaraan pembelajaran daring.

c. Menekan biaya penyelenggaraan pendidikan/pelatihan yang bermutu dengan memanfaatkan sumber daya bersama.

\subsection{Metode Penelitian}

Penelitian ini merupakan penelitian deskriptif. Penelitian deskriptif merupakan penelitian yang bertujuan untuk menyelidiki, memaparkan atau menggambarkan suatu keadaan, kondisi, atau hal-hal lain yang menjadi objek penelitian (Arikunto 2010). Berdasarkan hal tersebut maka, objek penelitian ini adalah problematika pembelajaran daring dan strategi pembelajaran daring pada mata kuliah Bahasa Indonesia. Penelitian ini bertujuan mendeskripsikan masalah-masalah dalam pembelajaran daring dan strategi pembelajaran daring yang diterapkan pada mata kuliah Bahasa Indonesia. Kegiatan pembelajaran MK Bahasa Indonesia ini dilakukan secara daring sejak Maret 2020 s.d. Mei 2020. Pengumpulan data dilakukan menggunakan teknik pengamatan dan 


\section{JURNAL ILMIAH \\ BINA EDUKASI \\ ISSN 1979-8598 E-ISSN: 2655-8378 \\ http://journal.binadarma.ac.id/index.php/jurnalbinaedukasi \\ Vol. 13, No. 1, Juni 2020, 01 -- 15}

dokumentasi. Pengamatan dilakukan dengan memperhatikan pola perilaku mahasiswa saat melaksanakan atau melakukan kegiatan pembelajaran daring. Data yang didokumentasikan adalah hasil latihan mahasiswa dan forum diskusi mahasiswa. Dokumentasi dilakukan dengan mengunduh data atau tangkapan layar (screenshot) forum diskusi mahasiswa. Analisis data dilakukan menggunakan model interakstif yang terdiri dari tiga tahapan, yaitu (1) mereduksi data, (2) memaparkan data, dan (3) menyimpulkan dan memverifikasi data (Gunawan 2014). Mereduksi data merupakan kegiatan memilih hal-hal pokok, merangkum, dan memusatkan pada hal penting, serta mencari tema dan pola juga membuang yang tidak penting (Sugiyono, 2011). Memaparkan data dalam sebuah kumpulan informasi yang sistematis sehingga memudahkan dalam penarikan kesimpulan dan pengambilan tindakan. Menyimpulkan dan memverifikasi data merupakan hasil penelitian yang menjawab fokus penelitian berdasarkan hasil pemaparan data (Miles \& Huberman dikutip Gunawan 2014).

\section{HASIL DAN PEMBAHASAN}

\subsection{Problematik Pembelajaran Daring}

Pada kegiatan pembelajaran daring mata kuliah Bahasa Indonesia terjadi beberapa problematik. Problematik tersebut terjadi pada beberapa komponen pembelajaran. Problematik pembelajaran daring yang tersebut juga dipengaruhi oleh beberapa faktor, baik internal maupun eksternal. Adapun problematik pembelajaran daring mata kuliah Bahasa Indonesia adalah sebagai berikut.

\subsubsection{Sarana dan Prasarana Pembelajaran}

E-learning sarana utama pada pembelajaran daring MK Bahasa Indonesia. Selain itu, sarana pendukung lainnya adalah surat elektronik (sur-el) dan whatsapp. Sarana tersebut dapat diakses menggunakan personal computer dan ponsel pintar yang terhubung dengan jaringan internet. Jaringan internet dapat digunakan jika pengajar dan pembelajar memiliki kuota internet di ponsel pintar atau memanfaatkan wi-fi.

E-learning digunakan sebagai media untuk mengunggah peraturan perkuliahan, RPS, materi pembelajaran, forum diskusi, serta mengunggah dan menilai latihan, tugas, KUIS, UTS, dan UAS. Kendalanya, mahasiswa tidak dapat memeriksa e-learning setiap waktu. Pemberitahuan dari e-learning tidak secepat pemberitahuan dari sur-el atau whatsapp. Jika mahasiswa tidak mensinkronisasi sur-el aktifnya pada ponsel pintar mereka, maka pemberitahuan dari sur-el pun lama diketahui oleh mahasiswa. Whatsapp dapat digunakan untuk kegiatan diskusi melalui grup-grup obrolan dengan umpan balik yang cepat antar anggota tetapi kegiatan berbagai dokumen melalui whatsapp tidak dapat dilakukan dalam skala besar. Sebab tidak semua mahasiswa mempunyai ponsel pintar terbaru dengan fitur-fitur canggih. Whatsapp dapat juga diakses melalui personal computer tetapi juga membutuhkan jaringan internet yang baik. 


\section{JURNAL ILMIAH \\ BINA EDUKASI \\ ISSN 1979-8598 E-ISSN: 2655-8378 \\ http://journal.binadarma.ac.id/index.php/jurnalbinaedukasi \\ Vol. 13, No. 1, Juni 2020, 01 -- 15}

Jaringan internet, kuota internet, dan wifi adalah penujang utama yang digunakan untuk mengakses e-learning, sur-el, dan whatsapp. Semakin besar dokumen atau media pembelajaran yang digunakan maka semakin membutuhkan kuotan internet yang banyak. Hal tersebut tentu berdampak pada kebutuhan pengajar dan pembelajar terhadap kuota internet maka biaya untuk kegiatan pembelajaran bertambah yaitu membeli kuota internet. Selain itu, bagi mahasiawa yang tinggal di pelosok dengan jaringan internet yang tidak baik maka kegiatan pembelajaran daring juga akan terhambat.

\subsubsection{Proses Pembelajaran}

Pembelajaran daring ini dilakukan secara penuh sejak Maret 2020. MK Bahasa Indonesia sedang diajarkan pada mahasiswa semester 2. Sebelumnya, pembelajaran daring masih menggunakan sistem blended learning. Sebelum memulai pembelajaran daring ini, pengajar menyusun dan mencantumkan ketentuan belajar sehingga mahasiswa memahami sistem pembelajaran daring ini. Dalam setiap minggu, proses pembelajaran daring MK Bahasa Indonesia terdiri dari empat aspek kegiatan pembelajaran, yaitu materi pembelajaran, tautan referensi, forum diskusi, dan latihan/tugas. Pada pembelajaran daring minggu-minggu sebelumnya, banyak mahasiswa yang hanya fokus mengerjakan latihan saja tetapi melewatkan pembacaan, penyimakan, dan pemahaman materi, tidak membuka dan mempelajari artikel yang dicantumkan melalui tautan referensi, dan tidak berpartisipasi dalam forum. Pada pembelajaran daring MK Bahasa Indonesia, ada mahasiswa yang belum bisa berdiskusi menggunakan forum diskusi pada e-learning.

\subsubsection{Tujuan Pembelajaran}

Tujuan umum pembelajaran MK Bahasa Indonesia adalah mahasiswa dapat menggunakan bahasa Indonesia yang baik dan benar dalam kegiatan berbahasa baik secara tulis maupun lisan. Tujuan khususnya adalah mahasiswa dapat menyusun karya tulis ilmiah, seperti makalah, tugas akhir, maupun skripsi. Dalam pembelajaran daring, pencapaian tujuan pembelajaran ini dilakukan menggunakan metode dan sarana pembelajaran yang berbeda dari kegiatan pembelajaran konvesional (tatap muka).

\subsubsection{Materi Pembelajaran}

Dalam pembelajaran daring MK Bahasa Indonesia, materi pembelajaran tidak dapat disajikan dengan format sederhana seperti power point saja. Pengajar harus menyajikan materi pembelajaran yang dapat dipahami oleh mahasiswa meski tidak dijelaskan secara langsung. Kendalanya, pengajar harus memperbaharui penyajian materi menjadi lebih lengkap. Seperti membuat power point yang dilengkapi oleh audio atau menyusun lembar kerja yang berisi tujuan pembelajaran, materi, contoh konkret, dan latihan dalam format dokumen pdf. Selain itu, pengajar juga perlu menyiapkan tautan referensi yang sesuai dengan materi yang sedang diajarkan. Oleh karena itu, pengajar perlu lebih giat lagi dalam meningkatkan kompetensi menyusun dan menyajikan bahan ajar sehingga kegiatan pembelajaran daring lebih efektif. 


\section{JURNAL ILMIAH \\ BINA EDUKASI \\ ISSN 1979-8598 E-ISSN: 2655-8378 \\ http://journal.binadarma.ac.id/index.php/jurnalbinaedukasi \\ Vol. 13, No. 1, Juni 2020, 01 -- 15}

\subsubsection{Metode Pembelajaran}

Metode dan teknik pembelajaran harus disesuaikan dengan sarana pembelajaran. Pengajar tidak lagi dapat menggunakan metode langsung, seperti metode ceramah dalam pembelajaran. Jika menggunakan metode langsung seperti video konferensi melalui aplikasi seperti: zoom, cloudx, webex, google meet, dll. tetapi hal tersebut dapat menimbulkan kendala dan memberatkan pembelajar yang berada di daerah dengan jaringan internet yang tidak lancar. Teknik diskusi juag tidak dapat dilakukan seperti diskusi pada saat pembelajaran tatap muka. Kegiatan diskusi hanya dapat dilakukan di forumforum diskusi atau grup-grup obrolan. Diskusi yang dilakukan di forum elearning tidak dapat dilakukan secara langsung, sebab tidak semua mahasiswa mengakses elearning secara bersamaan. Kegiatan tanya jawab juga tidak akan mendapatkan umpan balik dengan cepat.

\subsubsection{Subjek Pembelajaran}

Selain kesiapan sarana dan prasarana dalam pembelajaran daring, hal paling memerlukan kesiapan dari subjek pembelajaran. Subjek pembelajaran tentu akan mengalami banyak kendala dalam pembelajaran daring karena selama ini sudah sangat nyaman dengan sistem pembelajaran konvesional, yaitu tatap muka. Adapun subjek dalam pembelajaran adalah pengajar dan pembelajar. Pengajar dalam pembelajaran daring MK Bahasa Indonesia adalah dosen pengampu mata kuliah. Pembelajar adalah mahasiswa yang mengambil MK Bahasa Indonesia.

\section{a) Pengajar}

Pengajar mengalami banyak problematik dalam pembelajaran daring MK Bahasa Indonesia. Pengajar harus menyusun kontrak kuliah secara tertulis dengan jelas dan baik sehingga dapat dipahami mahasiswa. Pengajar juga harus menyusun dan membuat ulang penyajian materi menjadi lebih mudah untuk dipahami mahasiswa tanpa harus mendengar penjelasan secara langsung. Pengajar juga perlu menentukan, mempelajari, memilih, dan menvariasikan metode-metode ataupun teknik-teknik pembelajaran daring.

Seiring dengan kegiatan pembelajaran daring, pengajar juga harus menganalisis kebutuhan dan kesulitan yang dialami pembelajar saat mengikuti kegiatan pembelajaran daring. Pada pertemuan tatap muka, tidak setiap pertemuan harus berakhir dengan tugas atau latihan. Namun pada pembelajaran daring, dengan 4 aspek kegiatan yang salah satunya adalah latihan maka setiap pertemuan wajib ada latihan. Karena ada latihan, maka setiap minggu, pengajar juga wajib melakukan penilaian (grading). Bagi pengajar yang mengampu banyak kelas-kelas besar tentu hal tersebut menjadi masalah yang cukup serius.

Selain itu, proses pembelajaran daring MK Bahasa Indonesia dilakukan secara tidak langsung (asinkronus) dengan rentang waktu 1 minggu atau 6 hari. Oleh sebab itu, umpan balik dari kegiatan pembelajaran tidak dapat diperoleh dalam waktu yang cepat. Pengajar perlu mengorganisasi waktu untuk memeriksa dan memberikan umpan balik dalam kegiatan diskusi di e-learning. pembelajaran. merancang strategi pembelajaran yang berbeda-beda untuk tujuan dan materi pembelajaran tertentu. 


\section{JURNAL ILMIAH \\ BINA EDUKASI \\ ISSN 1979-8598 E-ISSN: 2655-8378 \\ http://journal.binadarma.ac.id/index.php/jurnalbinaedukasi \\ Vol. 13, No. 1, Juni 2020, 01 -- 15}

\section{b) Pembelajar}

Pada pembelajaran daring MK Bahasa Indonesia, pembelajar mengalami beberapa masalah, yaitu: (a) sarana pembelajaran dan (b) waktu kegiatan belajar atau jadwal pembelajaran. Sarana pembelajaran pada pembelajaran daring adalah jaringan internet dan paket internet (kuota). Selama masa pandemi ini, banyak mahasiswa dari luar daerah yang kembali ke kampung halaman mereka. Di beberapa daerah pelosok, jaringan internet sulit diperoleh. Hal tersebut menyebabkan kegiatan pembelajaran daring tidak dapat diikuti mahasiswa tepat waktu atau mengalami penundaan. Selain jaringan internet, mahasiswa juga harus mengeluarkan biaya tambahan untuk membeli kuota internet.

Kendala jaringan internet dan kuota juga memengaruhi waktu belajar mahasiswa. Sehingga mahasiswa kesulitan mengikuti kegiata belajar sesuai dengan jadwal. Karena tidak dapat mengikuti kegiatan pembelajaran daring sesuai waktunya, maka tugas-tugas MK Bahasa Indonesia akan menumpuk dengan tugas-tugas MK lainnya. Hal tersebut membuat mahasiswa menjadi keteteran dan tidak fokus dalam mengerjakan tugas ataupun latihan yang diberikan ataupun mengikuti pembelajaran daring MK Bahasa Indonesia.

\subsubsection{Penilaian Pembelajaran}

Kendala utama dalam penilaian pembelajaran daring MK Bahasa Indonesia adalah bentuk soal, penilaian sikap kejujuran mahasiswa, dan penyekoran (grading). Pada pembelajaran daring MK Bahasa Indonesia, penilaian dilakukan pada komponen kognitif, afektif, dan psikomotorik dari proses kegiatan pembelajaran. Komponen kognitif dinilai dari kegiatan latihan atau tugas, kuis, UTS, dan UAS. Bentuk soal pada tugas, latihan, KUIS, UTS, dan UAS juga disesuaikan dengan tujuan dalam bentuk jawaban pendek atau pilihan ganda. Pengajar memberikan soal-soal aplikatif sehingga mahasiswa dapat menerapkan pengetahuan yang telah dipelajari untuk mengerjakannya. Kendalanya adalah kelas MK Bahasa Indonesia terdiri dari jumlah yang besar sehingga pemeriksaan tugas atau latihan membutuhkan waktu yang lama. Dalam kelas-kelas besar, pemberian tugas dalam bentuk pilihan ganda memudahkan pengajar saat pemeriksaan dan penilaian, tetapi bentuk soal-soal tersebut hanya mengukur kemampuan kognitif pada tingkat pengetahuan dan pemahaman saja. Bahkan, pembelajar dapat mengisi dengan cara menebak atau 'asal-asalan'. Selain itu, pengajar juga harus menyiapkan bank soal. Penyusunan bank soal juga tidak dapat dilakukan dalam waktu singkat.

Beberapa sikap dalam komponen afektif dalam dinilai melalui kegiatan pembelajaran yang dilakukan mahasiswa. Pada komponen afektif, masalah yang paling sering terjadi pada penilaian pembelajaran adalah sikap 'ketidakjujuran' mahasiswa dalam mengerjakan tugas atau latihan. Mahasiswa seringkali menyalin-tempel jawaban yang telah dikerjakan oleh temannya. Pengalaman yang paling parah dari pengajar saat memeriksa tugas mahasiswa untuk dinilai adalah (1) mengunggah kembali dokumen soal latihan yang diberikan pengajar; (2) meminta orang lain mengakses akun e-learning dan mengerjakan tugasnya; (3) menggandakan lembar jawaban dengan tulisan tangan, kemudian menggunakannya untuk nama yang berbeda. 


\section{JURNAL ILMIAH \\ BINA EDUKASI \\ ISSN 1979-8598 E-ISSN: 2655-8378 \\ http://journal.binadarma.ac.id/index.php/jurnalbinaedukasi \\ Vol. 13, No. 1, Juni 2020, 01 -- 15}

Pada komponen psikomotorik, penilaian dilakukan berdasarkan kemampuan mahasiswa mengerjakan tugas sesuai dengan instruksi yang diberikan. Akan tetapi masih banyak mahasiswa yang tidak mengikuti instruksi saat mengerjakan tugas atau latihan yang diberikan.

Selain itu, komponen penilaian juga dilakukan pada keaktifan mahasiswa berpartisipasi pada forum tetapi banyak mahasiswa yang tidak berpartisipasi di forum. Pada awal perkuliahan, pengajar telah menyampaikan beberapa ketentuan perkuliahan secara daring. Salah satunya ialah, kehadiran mahasiswa pada kelas daring dilihat dari keaktifan mereka pada forum diskusi. Banyak dari mahasiswa yang mengikuti kelas daring MK Bahasa Indonesia hanya fokus mengerjakan latihan saja.

\subsection{Pemecahan Masalah yang telah Dilakukan untuk Meminimalisasi Problematik Pembelajaran Daring}

Adapun beberapa strategi yang dapat dilakukan untuk meminimalisasi probematik pembelajaran daring MK Bahasa Indonesia adalah sebagai berikut.

\subsubsection{Sarana, Prasarana, dan Proses Pembelajaran Daring}

Kelancaran ataupun kesulitan jaringan internet adalah faktor eksternal yang mempengaruhi proses pembelajaran daring melalui $e$-learning. Oleh sebab itu, baik pengajar maupun pembelajar tidak dapat mengorganisasinya. Sebaliknya, pengajar dapat mengatasi hal tersebut dengan menggunakan metode dan teknik pembelajaran daring, menyajikan materi pembelajaran, memberikan tugas yang tidak memerlukan bandwidth internet yang tinggi. Jadi, pengajar mengorganisasi pembelajaran daring dengan menggunakan bandwidth internet serendah mungkin. Sehingga, seluruh mahasiswa, baik yang berada di wilayah dengan jaringan intenet cepat maupun dii wilayah dengan jaringan internet lambat dapat mengikuti kegiatan pembelajaran daring sama baiknya.

Selain e-learning, pengajar juga mengkombinasikan kegiatan pembelajaran daring menggunakan sur-el dan whatsapp. Pada forum diskusi di pertemuan pertama, pengajar mengkoordinasi mahasiswa untuk membuat grup obrolan di whatsapp. Dengan membuat grup obrolan di whatsapp, pengajar dapat dengan cepat berkoordinasi dengan mahasiswa. Sebab, mahasiswa tidak selalu "stand by" mengakses $e$ learning maka pengajar dapat memberitahukan kesediaan materi yang telah diunggah ataupun tugas melalui whatsapp. Hal tersebut juga serupan dengan hasil penelitan yang dilakukan oleh Sofyana dan Rozaq (2019) yang menjelaskan bahwa pembelajaran daring dengan kombinasi whatsapp lebih efektif. Pengajar menggunakan sur-el sebagai alternatif bagi mahasiswa untuk mengumpulkan tugas atau jawaban latihan jika mengalami kesulitan mengakses e-learning.

Selain sarana dan prasarana pembelajaran, pengajar juga perlu menyusun ketentuan dan langkahlangkah pembelajaran daring khususnya untuk mahasiswa yang belum terbiasa menggunakan e-learning. Pengajar membuat panduan diskusi melalui forum di e-learning dan mengunggahnya di $e$-learning. Hal tersebut karena ada beberapa mahasiswa yang belum terbiasa menggunakan e-learning. 


\section{JURNAL ILMIAH \\ BINA EDUKASI \\ ISSN 1979-8598 E-ISSN: 2655-8378 \\ http://journal.binadarma.ac.id/index.php/jurnalbinaedukasi \\ Vol. 13, No. 1, Juni 2020, 01 -- 15}

\subsubsection{Tujuan, Materi, dan Metode Pembelajaran Daring}

Tujuan pembelajaran tetap harus dicapai meski melalui sistem pembelajaran yang berbeda. Pada pembelajaran daring, dengan mempertimbangkan tingkat bandwidth internet, pengajar dapat menyajikan materi dalam bentuk dokumen, power point dengan rekaman audio, maupun video. Penyajian materi dalam bentuk dokumen, pengajar lebih mengutamakan penggunaan format PDF. Dalam format tersebut materi yang tertulis dalam dokumen tidak akan mengalami perubahan posisi meski diakses dari personal computer ataupun ponsel pintar. Penyajian materi melalui power point dengan rekaman audio maupun video, maka pengajar perlu meluangkan waktu untuk membuat itu. Meski tidak sekaligus, pengajar mencicil penyusunan materi tersebut setidaknya satu materi setiap minggu.

Selain materi pembelajaran, pada MK Bahasa Indonesia juga disertai dengan tautan referensi. Tautan referensi ini juga dapat digunakan sebagai pelengkap materi pembelajaran atau sebagai salah satu media latihan bagi mahasiswa. Salah satu materi MK Bahasa Indonesia adalah Pedoman Umum Ejaan Bahasa Indonesia. Pengajar tidak dapat menautkan PUEBI dalam bentuk softcopy tetapi pengajar menggunakan tautan https://puebi.readthedocs.io/en/latest/ sebagai referensi. Mahasiswa mendapatkan materi lebih lengkap tentang PUEBI secara daring.

Agar mahasiswa membaca materi dan tautan referensi yang diberikan, pengajar memberikan latihan yang mengharuskan mahasiswa membaca materi dan tautan referensi. Misalnya: pada materi "Kutipan", pengajar memberikan tautan referensi berupa artikel ilmiah. Kemudian, soal pada latihan, pengajar menugaskan mahasiswa untuk mengidentifikasi jumlah kutipan, mengklasifikasi jenis kutipan, dan menilai teknik penulisan kutipan yang digunakan dalam artikel pada tautan referensi. Kegiatan tersebut merupakan salah satu teknik dalam metode pembelajaran discovery.

Selain membaca materi dan tautan referensi, serta mengerjakan latihan, keaktifan mahasiswa dalam pembelajaran daring MK Bahasa Indonesia juga dilihat dari partisipasi mahasiswa dalam diskusi baik pada forum diskusi di e-learning maupun forum diskusi di grup obrolan whatsapp. Untuk meningkatkan partisipasi mahasiwa dalam kegiatan diskusi, pengajar memberikan poin bagi mahasiswa yang mengajukan pertanyaan dan menjawab pertanyaan dari teman diskusi. Pada ketentuan kuliah daring, pengajar juga menghitung partisipasi mahasiswa dalam forum diskusi sebagai bukti kehadiran. Teknik ini cukup efektif untuk meningkatkan partisipasi mahasiswa dalam forum diskusi, baik melalui forum diskusi di e-learning mauun grup obrolan di whatsapp. Dari hal tersebut dapat diketahui bahwa, metode diskusi masih dapat dilakukan dalam pembelajaran daring yang bersifat tidak langsung (asinkronus).

\subsubsection{Subjek Pembelajaran Daring}

\section{a) Pengajar}

Sebelum mengatasi problematik pembelajaran daring, hal utama yang perlu dilakukan pengajar adalah menumbuhkan pemahaman bahwa sistem pembelajaran semakin berkembang dan maju. Oleh karena itu, pengajar tidak dapat terus berpaku pada sistem pembelajaran konvesional. Pengajar harus terus 


\section{JURNAL ILMIAH \\ BINA EDUKASI \\ ISSN 1979-8598 E-ISSN: 2655-8378 \\ http://journal.binadarma.ac.id/index.php/jurnalbinaedukasi \\ Vol. 13, No. 1, Juni 2020, 01 -- 15}

belajar memperbarui kemampuan mengajarnya dan menyesuaikan dengan perkembangan sistem pendidikan yang semakin maju.

Sebelum memulai pembelajaran daring MK Bahasa Indonesia, pengajar menyusun ketentuan pembelajaran daring dan mencantumkannya pada kelas e-learning. Hal tersebut dilakukan agar mahasiswa yang baru mengikuti kegiatan pembelajaran daring mengetahui sistem pembelajaran daring yang diikutinya. Ketentuan pembelajaran daring ini sama dengan kontrak kuliah pada pertemuan tatap muka. Pengajar mengampu MK Bahasa Indonesia untuk mahasiswa semester 2 yang memulai pembelajaran daring secara penuh semester genap ini.

Problematik pengajar dalam menyusun dan menyajikan materi untuk pembelajaran daring. Pengajar mengikuti beberapa pelatihan pembelajaran daring di tahun 2019. Kemudian, pengajar belajar secara mandiri membuat power point dengan rekaman audio. Setelah itu, pengajar belajar menyusun ulang power point dilengkapi dengan rekaman audio. Selain itu, pengajar juga menyusun materi ajar dalam bentuk lembar kerja atau modul untuk setiap tujuan pembelajaran (per bab/ per materi) sehingga lebih mudah dibaca oleh pembelajar.

Penyajian materi dan pemilihan metode pembelajaran juga harus disesuaikan dengan kemampuan mahasiswa, terutama dalam pengaksesan jaringan internet. Pengajar dan mahasiswa dapat berdiskusi di grup jika ada kendala dalam mengakses materi pembelajaran di e-learning. Saat masa Karantina Wilayah dan PSBB, mahasiswa yang sedang dikarantina tidak bisa mengikuti kegiatan pembelajaran tepat waktu, maka pengajar memberik kelonggaran bagi mahasiswa-mahasiswa tersebut untuk menyusul (back up) kegiatan pembelajaran daring sebelumnya. Dalam pembelajaran daring, pengajar harus lebih fleksibel dalam menghadapi kendala yang dialami oleh mahasiswa. Sebab kendala tersebut terjadi diakibatkan oleh faktor eksternal yang tidak diantisipasi sebelumnya.

\section{b) Pembelajar}

Problematik pembelajar adalah waktu pembelajaran daring yang terkadang terhambat oleh jaringan internet yang buruk atau kuota internet. Pengajar dapat memberikan saran kepada pembelajar untuk selalu mengikuti kegiatan pembelajaran sesuai dengan jadwal yang telah diberikan oleh pihak akademik universitas. Pengajar juga bisa memberikan pengaturan rentang waktu mengerjakan tugas dan forum diskusi kepada mahasiswa sehingga mereka tidak 'terlena' dengan sistem pembelajaran daring ini. Jika tidak diberi rentang waktu, ada mahasiswa yang mengerjakan latihan yang telah lewat waktunya.

Jika, jaringan internet tidak berfungsi dengan baik untuk mengakses e-learning, sur-el, maupun whatsapp, mahasiswa dapat menghubungi pengajar melalui panggilan telepon atau email. Pada awal perkuliahan daring, pengajar juga perlu menjelaskan ketentuan tentang menghubungi dosen kepada mahasiswa. Karena kegiatan pembelajaran daring dilakukan dari rumah, pengajar dapat mengimbau mahasiswa untuk mengalokasikan uang saku hariannya untuk membeli kuota internet. Selain itu, saat ini beberapa provider selular menawarkan paket-paket kuota internet yang terjangkau bagi mahasiswa. Pihak 


\section{JURNAL ILMIAH \\ BINA EDUKASI \\ ISSN 1979-8598 E-ISSN: 2655-8378 \\ http://journal.binadarma.ac.id/index.php/jurnalbinaedukasi \\ Vol. 13, No. 1, Juni 2020, 01 -- 15}

universitas juga melakukan kerja sama dengan perusahaan provider untuk memberikan potongan biaya kuota internet bagi pengajar dan mahasiswa.

\subsubsection{Penilaian Pembelajaran Daring}

Bentuk soal latihan yang digunakan dalam latihan, KUIS, UTS, dan UAS pada MK Bahasa Indonesia adalah soal esai dan tugas menulis. Selain itu, pengajar berupaya meminimalisasi kecurangan dalam pengerjaan tugas, KUIS, UTS, dan UAS dengan memberikan beberapa instruksi pengerjaan latihan atau tugas. Misalnya pada saat KUIS, UTS, atau UAS, pengajar meminta mahasiswa untuk menulis jawaban secara manual atau menggunakan tulisan tangan. Kemudian lembar jawaban tersebut dipindai dan disimpan dalam format $P D F$. File jawaban juga harus dinamai (rename) dengan ketentuan 'nama_KUIS'. Pengajar juga memberikan rentang waktu satu hari untuk pengerjaan KUIS, UTS, atau UAS.

Dengan instruksi-instruksi tersebut, pengajar dapat meminimalisasi kecurangan yang dilakukan mahasiswa dalam mengerjakan KUIS, UTS, atau UAS, Selain itu, pengajar juga bisa menilai sikap disiplin dan taat dari mahasiswa. Mahasiswa yang mengikuti instruksi dengan tepat dapat dinilai kedisiplinan dan ketaatannya terhadap instruksi yang diberikan. Jika, pengajar meminta mahasiswa menjawab latihan atau tugas secara daring pada laman latihan mereka di e-learning maka ada beberapa teknik yang dapat digunakan untuk mendeteksi kecurangan jawaban mahasiswa. Pertama, pada pengaturan assignment, pengajar membatasi jumlah kata dari jawaban mahasiswa. Misalnya, pada materi 'Paragraf', pengajar menugaskan mahasiswa untuk membuat paragraf lebih kurang 150 kata. Kedua, pengajar mengindentifikasi waktu pengunggahan jawaban mahasiswa dan dibandingkan dengan jumlah kata pada jawaban mahasiswa. Ketiga, jika ada kesamaan jumlah kata, pengajar akan mengidentifikasi kemiripan kalimat dan kata yang digunakan untuk menyusun paragraf pada jawaban mahasiswa.

Salah satu bentuk penilaian lainnya adalah partisipasi mahasiswa dalam forum diskusi. Pengajar memberikan poin bagi mahasiswa yang berpartisipasi dalam kegiatan diskusi. Pemberian nilai ini juga merupakan teknik untuk meningkatkan semangat dan minat mahasiswa dalam berpartisipasi dalam kegiatan diskusi forum.

\section{SIMPULAN}

Dalam pembelajaran daring, sarana dan prasarana pembelajaran harus memadai. Pembelajaran daring MK Bahasa Indonesia menggunakan e-learning, sur-el, dan whatsapp untuk memperlancar proses pembelajaran daring. Kendala kesulitan jaringan internet yang tidak sulit diakses di beberapa wilayah dapat diatasi dengan mengunakan format penyajian materi dan pengerjaan tugas yang tidak membutuhkan bandwidth internet yang tinggi.

Penyajian materi dan pemilihan metode pembelajaran dalam pembelajaran daring juga harus jelas dan tepat. Penyajian materi dapat berupa dokumen (lembar kerja atau modul) atau 


\section{JURNAL ILMIAH \\ BINA EDUKASI \\ ISSN 1979-8598 E-ISSN: 2655-8378 \\ http://journal.binadarma.ac.id/index.php/jurnalbinaedukasi \\ Vol. 13, No. 1, Juni 2020, 01 -- 15}

power point dengan rekaman audio lebih mudah diakses menggunakan jaringan internet dengan bandwidth internet yang rendah daripada video konferensi. Metode pembelajaran harus lebih fleksibel dan bervariasi serta disesuaikan dengan sarana dan prasarana pembelajaran daring yang dapat diakses oleh seluruh mahasiswa. Pemberian tugas atau latihan juga menjadi strategi untuk mengukur kemampuan mahasiswa dalam belajar secara mandiri.

Pengajar juga harus selalu belajar untuk meningkatkan kemampuan dalam menyusun dan menyajikan materi yang sesuai dengan pembelajaran daring. Pengajar juga harus mulai membuat dan menabung soal-soal pilihan ganda supaya saat mendapat kelas yang besar tidak lagi kesulitan. Dengan mengikuti berbagai pelatihan dan seminar, pengajar dapat menambah pengetahuan tentang teknik-teknik pembelajaran daring. Pengajar juga harus terus memotivasi mahasiswa untuk dapat dan semangat belajar secara mandiri dan jujur dalam pembelajaran daring.

Sesempurna apapun persiapan pengajar dalam pembelajaran daring ini, tentunya masih akan banyak problematik yang ditemui. Pengajar harus selalu berkomunikasi dengan mahasiswa untuk meminimalisasi problematik yang dialami dan meningkatkan efektivitas pembelajaran daring. Tujuan pembelajaran akan dapat tercapai jika semua komponen belajar dapat dijalankan sebagaimana mestinya melalui sistem pembelajaran daring.

\section{DAFTAR PUSTAKA}

Arikunto, Suharsimi. (2010). Prosedur Penelitian: Suatu Pendekatan Praktik. Jakarta: PT Rineka Cipta.

Bilfaqih, Yusuf, dan M. Nur Qomarudin. (2015). Esensi Pengembangan Pembelajaran Daring. Yogyakarta: Deepublish Publisher.

Gunawan, Imam. (2014). Metode Penelitian Kualitatif: Teori dan Praktik. Jakarta: Bumi Aksara.

Hayati, Sri. (2017). Belajar dan Pembelajaran Berbasis Cooperative Learning. Jakarta: Graha Cendikia.

Mustofa, Mokhamad Iklil, Muhammad Chodzirin, Lina Sayekti, dan Roman Fauzan. (2019). "Formulasi Model Perkuliahan Daring Sebagai Upaya Menekan Disparitas Kualitas Perguruan Tinggi." Walisongo Journal of Information Technology 1(2):151-60.

Riyana, Cepi. (2011). Kurikulum Pembelajaran. (Online). http://file.upi.edu/Direktori/FIP/JUR._PEND._LUAR_BIASA/196209061986011AHMAD_MULYADIPRANA/PDF/Komponen_Pembelajaran.pdf. Diunduh pada 25 April 2020.

Riyanda, Afif Rahman, Kartini Herlina, dan B. Anggit Wicaksono. (2020). Evaluasi Implementasi Sistem Pembelajaran Daring Fakultas Keguruan Dan Ilmu Pendidikan Universitas Lampung. IKRA-ITH HUMANIORA: Jurnal Sosial Dan Humaniora 4(1):66-71. 


\section{JURNAL ILMIAH}

BINA EDUKASI

ISSN 1979-8598 E-ISSN: 2655-8378

http://journal.binadarma.ac.id/index.php/jurnalbinaedukasi

Vol. 13, No. 1, Juni 2020, 01 -- 15

Sofyana, Latjuba, dan Abdul Rozaq. (2019). Pembelajaran Daring Kombinasi Berbasis Whatsapp Pada Kelas Karyawan Prodi Teknik Informatika Universitas Pgri Madiun. Jurnal Nasional Pendidikan Teknik Informatika : JANAPATI 8(1):81-86.

Sugiyono, Sugiyono. (2011). Metode Penelitian Pendidikan. Bandung: Alfabeta.

Winataputra, Udin. S., Paulina Pennen, Dina Mustafa, Refni Delfi, dan Dewi Andriyani. (2016). Teori Belajar dan Pembelajaran. Edisi 1. Tangerang: Universitas Terbuka. 